\title{
Computational Approaches to Investigate and Design Lipid-binding Domains for Membrane Biosensing
}

\author{
Sriraksha Srinivasan and Stefano Vanni ${ }^{*}$
}

\begin{abstract}
Association of proteins with cellular membranes is critical for signaling and membrane trafficking processes. Many peripheral lipid-binding domains have been identified in the last few decades and have been investigated for their specific lipid-sensing properties using traditional in vivo and in vitro studies. However, several knowledge gaps remain owing to intrinsic limitations of these methodologies. Thus, novel approaches are necessary to further our understanding in lipid-protein biology. This review briefly discusses lipid-binding domains that act as specific lipid biosensors and provides a broad perspective on the computational approaches such as molecular dynamics (MD) simulations and machine learning (ML)-based techniques that can be used to study protein-membrane interactions. We also highlight the need for de novo design of proteins that elicit specific lipid-binding properties.
\end{abstract}

Keywords: de novo Design · Lipid-binding domains · Lipid-sensing · MD simulations

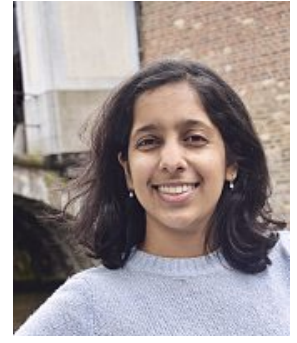

Sriraksha Srinivasan is pursuing a $\mathrm{PhD}$ in Computational Biology at the University of Fribourg in Switzerland under the supervision of Prof. Stefano Vanni. She uses molecular dynamics simulations to study how lipid transfer proteins function at membrane contact sites. She received her master's degree in Analytical Chemistry from St. Joseph's College, Bangalore, India in 2018.

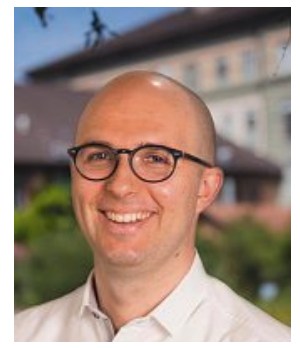

Stefano Vanni studied Physics at the University of Bologna, Italy, where he received his BSc and MSc in Theoretical Physics. Later, he obtained his $\mathrm{PhD}$ in the field of Computational Chemistry and Biochemistry at EPF, Lausanne, before joining the Institut de Pharmacologie Cellulaire et Moleculaire at CNRS in Sophia Antipolis, France, as a postdoctoral fellow. Since 2015, he is a tenured researcher at CNRS, and since 2017, he is a Swiss National Science Foundation Associate Professor in the Department of Biology at the University of Fribourg. Since 2018 he is affiliated to the NCCR in Bio-Inspired Materials. His main research focus is the molecular understanding of the role of membrane and lipid physicochemical properties in intracellular trafficking processes and lipid metabolism.

\section{Introduction}

Lipid bilayers are functional barriers that compartmentalize cell organelles and define boundaries between the internal constituents of a cell and its external environment. In addition to serving as structural components of membranes, lipids also act

Correspondence: Prof. S. Vanni, E-mail: stefano.vanni@unifr.ch

Department of Biology, University of Fribourg, Switzerland as reservoirs for energy storage ${ }^{[1]}$ and as messengers in signal transduction and molecular recognition processes. ${ }^{[2]}$ Membranes of cellular organelles are typically composed of fatty acids, glycerolipids, phospholipids, sphingolipids, sterols, and other lipid species in different concentrations. The chemical architecture of most lipids is characterized by a distinct polar headgroup (e.g. phosphocholine, phosphoethanolamine, phosphoinositide, phosphoserine), one or more acyl chains of different lengths, that could be saturated, mono-, or poly-unsaturated, and a backbone (such as: glycerol for glycerolipids and glycerophospholipids, sphingosine for sphingolipids).[3] Ongoing lipidome-cataloguing efforts indicate that, as a consequence of the combinatorial possibilities of different head groups, backbones, acyl chain lengths, and chain saturations, there are more than 46000 different lipid types in total. ${ }^{[4]}$ The lipid composition varies not only between different organelles of the cell, but also between leaflets of the same bilayer as well as within the same leaflet. [5]

Several intriguing questions have entranced lipid biology researchers over the last few decades - Why does the cell invest a substantial amount of resources in producing and maintaining this large repertoire of lipid species? What is the evolutionary significance of this heterogeneity? Where are each of these lipids produced? By what enzymatic reactions? Where are they redistributed to? And by what mechanism?

Hence, it is no surprise that several experimental techniques have also been developed ${ }^{[6]}$ in the last few decades in the attempt to solve these long-standing challenges. Fluorescent lipid-tagging is one such widely used method to study the localization and movement of lipids within the cell. In this approach, a fluorophore is conjugated to either the lipid head group (example Rhodamine-labelled $\mathrm{PE}^{[7]}$ ) or to the hydrophobic tail (as in the case of BODIPY-cholesterol $\left.{ }^{[8]}\right)$. However, some drawbacks of this method are that the labelled lipid could have different physicochemical properties, thus resulting in different membrane characteristics. For example, they could follow different metabolic routes compared to that of their endogenous counterparts, and they could potentially metabolize into species that cannot be distinguished via fluorescence or that cannot be transported by the same non-vesicular pathways. Another approach to probe lipids is the use of antibodies, ${ }^{[9,10]}$ such as anti-LysoBisPhosphatidic Acid 
(LBPA). ${ }^{[11]}$ A key disadvantage of this method is that their visualization requires cells to be fixed. However, lipids do not fix very well and remain mobile, which could result in false deductions. A third strategy to determine cellular distribution of lipids capitalizes on proteins that possess specific lipid-binding domains, such as the pleckstrin homology (PH) or $\mathrm{C} 2$ domains. Two main advantages of this method are that it allows visualization of lipids in live cells and that it has minimal effects on altering lipid distribution and metabolism.

In this review, we focus on the use of peripheral membrane proteins that contain lipid-binding domains as lipid sensors. We summarize the different lipid-binding domains in the cell that are used to probe cellular localization and function of lipids, the experimental approaches in place, their caveats, and the in silico techniques such as molecular dynamics (MD) simulations, machine learning (ML), and de novo protein design, that can help fill the gaps.

\section{Lipid-binding Domains as Biosensors}

Lipid-binding domains are extensively used as genetically encoded lipid biosensors for visualizing lipids in cells. ${ }^{[12,13]}$ They are typically expressed as fusions with fluorescent proteins such as GFP or mCherry and can be visualized via fluorescence microscopy. While some domains are highly stereospecific and have distinct lipid-binding partners, as shown in Table 1, some others are non-specific and sense general physical properties of the membrane such as charge, ${ }^{[14]}$ curvature ${ }^{[15]}$ or lipid-packing defects. ${ }^{[16]}$ Fig. 1 illustrates the diversity of lipid-binding folds for some representative lipid-binding proteins.

A closer look at Table 1 reveals that while acidic phospholipids, such as PA and many PIPs, have several corresponding lipid-binding domains, many lipids (such as phosphatidylcholine (PC), phosphatidylethanolamine (PE), phosphatidylinositol (PI), or ceramides) have few or no corresponding proteins that can bind with suitable affinity. While assays such as the LiMA ${ }^{[49]}$
Table 1. A non-exhaustive list of lipid-binding domains commonly used to visualize lipids and their localization.

\begin{tabular}{|c|c|c|c|}
\hline Lipid & Protein-Domain/ Motif & $\begin{array}{c}\text { Cellular } \\
\text { Localization }\end{array}$ & Reference \\
\hline Cholesterol & $\begin{array}{c}\text { Perfringolysin-O D4+ } \\
\text { its mutants } \\
\text { WCR-eOsh4 }\end{array}$ & $\begin{array}{c}\text { PM } \\
\text { Inner PM }\end{array}$ & $\begin{array}{l}{[17]} \\
{[18]}\end{array}$ \\
\hline DAG & PKCe-C1 & ER, NE & [19] \\
\hline PA & $\begin{array}{c}\text { Opilp-PABD } \\
\text { Sos1-PH } \\
\text { Spo20p-PABD+PASS }\end{array}$ & $\begin{array}{l}\text { ER, PM } \\
\text { PM } \\
\text { ER, PM }\end{array}$ & $\begin{array}{l}{[20]} \\
{[21]} \\
{[22]}\end{array}$ \\
\hline $\mathrm{PI}(3,4,5) \mathrm{P}_{3}$ & $\begin{array}{c}\text { Akt-PH }^{\mathrm{a}} \\
\text { ARNO-PH }^{\mathrm{a}} \\
\text { Btk-PH }^{\mathrm{a}} \\
\text { Cytohesin1-PH } \\
\text { GRP1-PH }\end{array}$ & $\begin{array}{l}\text { PM } \\
\text { PM } \\
\text { PM } \\
\text { PM } \\
\text { PM }\end{array}$ & $\begin{array}{c}{[23]} \\
{[24]} \\
{[25]} \\
{[24]} \\
{[23,24,26]}\end{array}$ \\
\hline $\mathrm{PI}(3,4) \mathrm{P}_{2}$ & TAPP1-PH & PM & [27] \\
\hline $\mathrm{PI}(3,5) \mathrm{P}_{2}$ & $\begin{array}{c}\text { Cti6 } \\
\text { Ent3p-ENTH }\end{array}$ & $\begin{array}{c}\text { Yeast nucleus } \\
\text { Yeast endosomes }\end{array}$ & $\begin{array}{l}{[28]} \\
{[29]}\end{array}$ \\
\hline $\mathrm{PI}(4,5) \mathrm{P}_{2}$ & $\begin{array}{l}\text { AP180-ENTH }{ }^{\mathrm{a}} \\
\text { PLCd1-PH } \\
\text { PLCd4-PH } \\
\text { Tubby domain }\end{array}$ & $\begin{array}{l}\text { PM } \\
\text { PM } \\
\text { PM } \\
\text { PM }\end{array}$ & $\begin{array}{l}{[30]} \\
{[31]} \\
{[32]} \\
{[33]}\end{array}$ \\
\hline PI3P & $\begin{array}{l}\text { EEA1-FYVE } \\
\text { Hrs-FYVE } \\
\text { p40phox-PX }\end{array}$ & $\begin{array}{l}\mathrm{EE} \\
\mathrm{EE} \\
\mathrm{EE}\end{array}$ & $\begin{array}{l}{[34]} \\
{[34]} \\
{[35]}\end{array}$ \\
\hline PI4P & $\begin{array}{l}\text { FAPP1-PH } \\
\text { OSBP1-PH } \\
\text { Osh2-PH } \\
\text { SidM-P4M } \\
\text { SidC-P4C }\end{array}$ & $\begin{array}{c}\text { Golgi } \\
\text { Golgi } \\
\text { PM } \\
\text { Golgi, PM, endosomes } \\
\text { Golgi, PM, endosomes }\end{array}$ & $\begin{array}{c}{[36,37]} \\
{[38]} \\
{[39]} \\
{[40]} \\
{[41,42]}\end{array}$ \\
\hline PI5P & ING2-PHD & PM, nucleus & [43] \\
\hline PS & Lactadherin- $\mathrm{C} 2^{\mathrm{a}}$ & PM, endosomes & {$[44]$} \\
\hline SM & $\begin{array}{c}\text { Lysenin } \\
\text { Equinatoxin II-SM } \\
\text { OlyAb }\end{array}$ & $\begin{array}{c}\text { PM } \\
\text { Golgi, PM } \\
\text { PM }\end{array}$ & $\begin{array}{l}{[45]} \\
{[46]} \\
{[47]}\end{array}$ \\
\hline \multicolumn{4}{|c|}{$\begin{array}{l}\text { aAlso binds selectively to other lipids; }{ }^{b} \text { Detects sphingomyelin complexed with cholesterol; Abbreviations } \\
\text { used: DAG, diacylglycerol; PA, phosphatidic acid; } \mathrm{PI}(3,4,5) \mathrm{P}_{3} \text {, phosphatidylinositol 3,4,5- trisphosphate; } \\
\mathrm{PI}(3,4) \mathrm{P}_{2} \text {, phosphatidylinositol 3,4-bisphosphate; } \mathrm{PI}(3,5) \mathrm{P}_{2} \text {, phosphatidylinositol 3,5-bisphosphate; } \\
\mathrm{PI}(4,5) \mathrm{P}_{2} \text {, phosphatidylinositol 4,5-bisphosphate; } \mathrm{PI} 3 \mathrm{P} \text {, phosphatidylinositol 3-phosphate; PI4P, } \\
\text { phosphatidylinositol 4-phosphate; PI5P, phosphatidylinositol 5-phosphate; PS, phosphatidylserine; SM, } \\
\text { sphingomyelin; EE, early endosome; ER, endoplasmic reticulum; NE, nuclear envelope; PM, plasma } \\
\text { membrane. }\end{array}$} \\
\hline
\end{tabular}


A
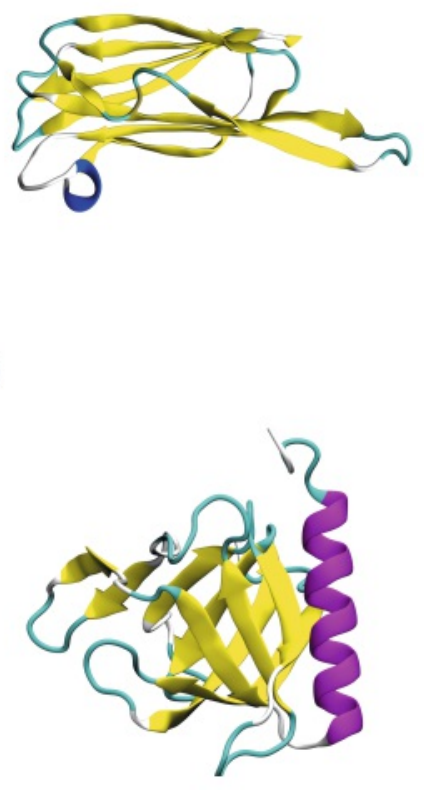

G

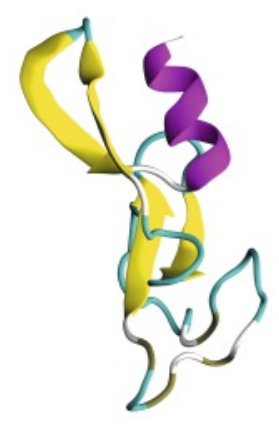

J

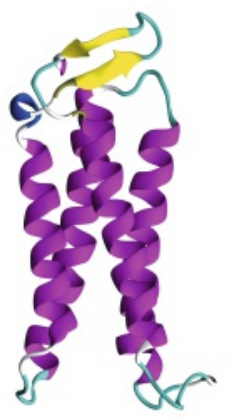

B

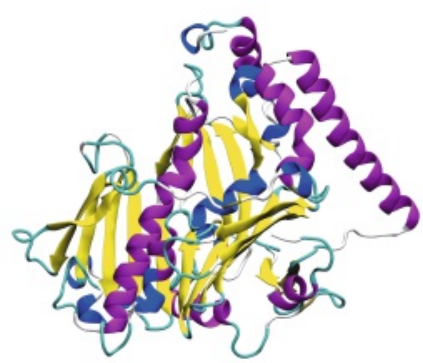

$\mathrm{E}$

C

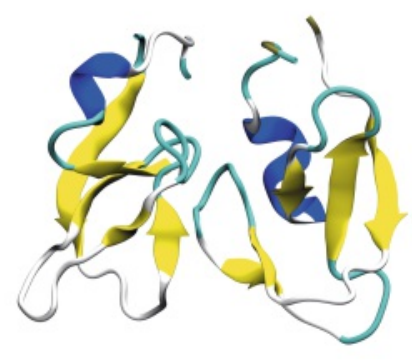

F

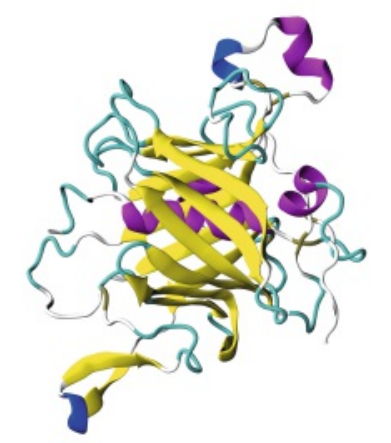

I

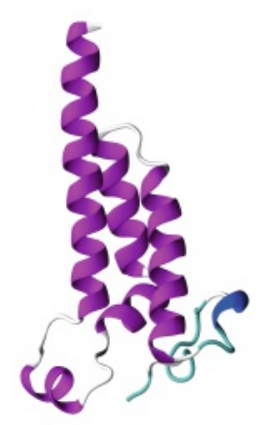

K
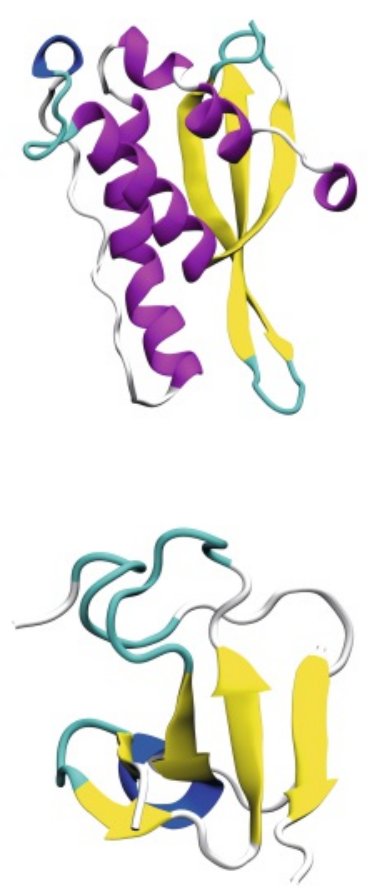

$\mathrm{L}$

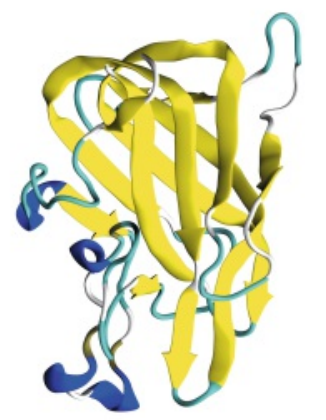

(Liposome-Microarray-based Array) that screen and quantify protein-membrane binding in vitro, can potentially also be used to identify novel specific probes for lipids, progress remains to be made on this front.

A second drawback is that many of these proteins could act as coincidence detectors, i.e. they could bind to additional lipids or other factors at a second binding site, thus biasing their localization. For example, the PH domains of OSBP, FAPP1, and yeast Osh2, all have a lipid-binding site and can serve as a PI4P probe. ${ }^{[50]}$ Yet, the PH domains of OSBP and FAPP1 localize to the Golgi apparatus since they also bind to Arf1 GTPase, ${ }^{[37]}$ while that of the Osh2 exhibits strong plasma membrane localization due to its interaction
Fig. 1. Secondary structures of some lipid-binding domains, indicating the diversity of their folds. (A) Domain-4 of Perfringolysin-O (PDB ID: 1M31) (B) OSBP domain of yeast Osh4 (PDB ID: 1ZHX)

(C) C1A and C1B domains of PKCe (structure from AlphaFold) (D) PH domain of GRP1 (PDB ID: 1FGZ) (E) ENTH domain of Ent3p (PDB ID: 3ONK) (F) Tubby domain (structure from AlphaFold) (G) FYVE domain of EEA1 (PDB ID: 1HYI) (H) PX domain of p40phox (PDB ID: 1H6H) (I) P4M domain of SidM (PDB ID: 4MXP) (J) P4C domain of SidC (PDB ID: 4ZUZ) (K) PHD domain of ING2 (PDB ID: 2G6Q) (L) C2 domain of Lactadherin (PDB ID: 3BN6). Alpha helices and beta-strands are colored violet and yellow respectively. Protein images were rendered using VMD. ${ }^{[48]}$ with $\mathrm{PI}(4,5) \mathrm{P}_{2} \cdot{ }^{\left[{ }^{39]}\right.}$ Several proteins also exhibit dual lipid recognition as in the case of Akt1- and PDK1-PH domains that bind to $\mathrm{PS}^{[51]}$ as well as $\mathrm{PI}(3,4,5) \mathrm{P}_{3}{ }^{\text {[52] }}$ Hence care must be taken when using lipid-binding domains as probes for lipids. These caveats highlight the pressing need for tools and methodologies that can (1) determine all lipid-binding sites and interfaces of proteins, as well as their lipid specificity, and (2) design artificial membranebinding proteins that exhibit specific lipid-interacting properties. In this context, several computational approaches have emerged as promising strategies and have been extensively used in the last two decades, some of which we discuss here. 


\section{Computational Approaches to Study Protein-Lipid Interactions}

Peripheral membrane proteins often interact transiently and reversibly with membranes. ${ }^{[53]}$ Hence, the $3 \mathrm{D}$ structures of most peripheral membrane proteins are generally determined in their soluble, membrane-less conformation. This makes it impossible to determine, based solely on the solved 3D structure, their membrane-binding interface. In addition, protein dynamical properties such as membrane binding-driven conformational changes or energetic and kinetic details of the binding process, are missing.

In this context, MD simulations have emerged as a promising approach to study protein-membrane interactions and have fueled our understanding of how peripheral membrane proteins bind to bilayers and which specific lipids or membrane properties they sense. ${ }^{[16,54-59]}$ To this extent, in the last few decades, all atom (AA) MD simulations have been useful in determining the interactions between proteins and bound lipids as well as characterizing protein-membrane interactions..$^{[57,59-63]}$ However, in many instances, membrane binding takes place on timescales that are longer than those accessible to unbiased AA-MD simulations. ${ }^{[64]}$

To address this limitation, techniques to enhance the sampling of this process have been put forward. Most notably, two techniques that have been used extensively for this purpose are (i) the highly mobile membrane-mimetic model (HMMM) ${ }^{[65]}$ and (ii) coarse grain (CG) simulations. In HMMM, the hydrophobic core of the bilayer is replaced by an organic solvent layer, while the polar heads are represented by short-tail phospholipids using an AA force-field (CHARMM36). This workaround strongly accelerates the lateral diffusion of lipids, in turn promoting membrane binding by peripheral proteins.[66] However, due to the overstabilization of aromatic, polar, and charged side chains in the membrane core, ${ }^{[67]}$ as well as to a general over-binding of proteins to the bilayer, ${ }^{[65]}$ this methodology is not well-suited to study the specificity of proteins to bilayers of different lipid compositions.

CG force-fields, on the other hand, allow the study of long timescale and large sizescale processes by treating three or four heavy atoms as a single interaction site, thus drastically reducing the computational cost. While CG approaches possess intrinsic limitations arising from a decrease in the resolution of the model, such as the absence of H-bonds and inaccurate entropydependent properties, ${ }^{[68]}$ force-fields such as the MARTINI[69,70] have been shown to hold enormous potential towards identifying membrane binding regions of proteins as well as characterizing their sensitivity for membrane properties such as electrostatics or lipid packing defects. ${ }^{[71]}$ Some noteworthy examples include the use of MARTINI to determine the interaction modes of several PIP-binding PH domains, ${ }^{[54,55,58,72]}$ PTEN domains, ${ }^{[73]}$ proteins that bind via their aromatic residues, ${ }^{[74]}$ and lipid-transfer proteins such as cholesteryl ester transfer protein (CETP) ${ }^{[75]}$ and $\alpha$-tocopherol transfer protein $\left(\alpha\right.$-TTP), ${ }^{[76]}$ to name a few.

\section{In silico Design of Lipid-binding Proteins}

Until recently, a major limitation of using MD simulations to investigate membrane-protein binding was the unavailability of 3D structures for many proteins. However, with the advent of AlphaFold 2 which predicts protein structures from their amino acid sequence with very high accuracy, ${ }^{[77]}$ this problem has now been alleviated. This opens the possibility to potentially screen multiple protein structures to predict their lipid-binding specificity and membrane-binding interface. This approach could help attenuate a major limitation of in vitro liposome-binding experiments, where genome-wide identification of peripheral membrane proteins via experimental methods remains a laborious and expensive endeavor. In fact, although sequence similarities with other peripheral membrane proteins can be predicted, the results are not always reliable as in the case of several PH domains that exhibit stark differences in membrane binding. ${ }^{[78]}$ This MD-based screening approach could also be partnered by ML-based techniques. Recently, in fact, ML studies have shown to be particularly useful in identifying peripheral membrane-binding proteins with an accuracy greater than $90 \%{ }^{[79]}$ as well as in predicting their membrane-binding interfaces. ${ }^{[80]}$ Another recent in silico approach to identify peripheral membrane proteins is based on the discovery that hydrophobic residues are more frequently found in protruding sites on peripheral membrane proteins than in other proteins, and that these residues cluster at sites that constitute the membrane-binding interface. ${ }^{[81]}$

A serious hiccup in using proteins as lipid biosensors, as discussed earlier, is that there exist only a few proteins that have been experimentally characterized to bind lipids such as PC, PE, and ceramides. Thus, a potentially interesting approach would be the computational design of proteins and peptide sequences that fold

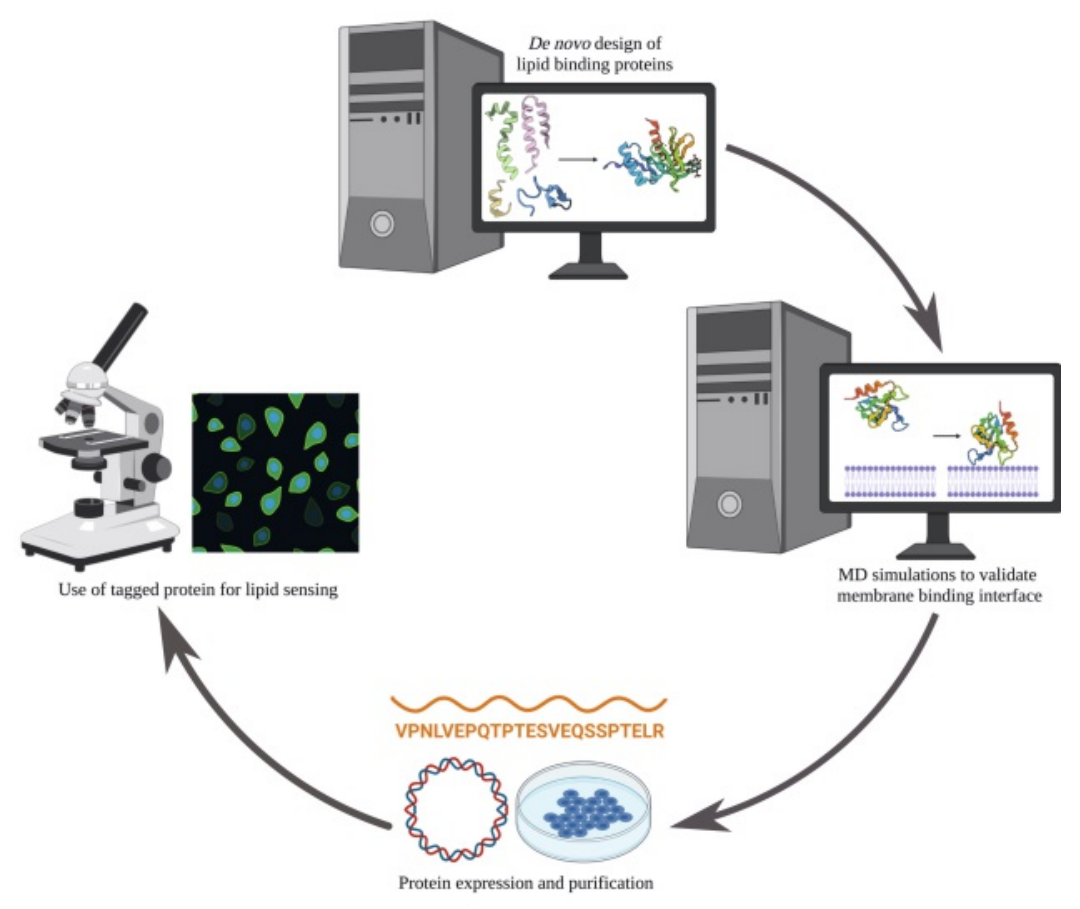

Fig. 2. Potential pipeline for the de novo design of lipid biosensors. Image created with BioRender.com 
into desired 3D structures and elicit specific lipid-binding properties. Over the last two decades, several proteins have been either successfully redesigned from existing protein structures, ${ }^{[82,83]}$ or de novo designed ${ }^{84,85]}$ to perform specific functions. Protein redesign approaches are limited to sampling the conformational space around an existing structure, thus enabling one to rigorously sample backbone and side chain conformations at the functional site. On the other hand, de novo design approaches lack an experimental structure to start with, thus making it possible to incorporate structural features not found in naturally occurring proteins. A typical de novo protein design pipeline involves:

1. Sampling the backbone structure space to identify backbones compatible with the desired function. This can be achieved by using fragment libraries derived from existing protein data bank (PDB) ${ }^{[86]}$ structures (as in the case of methods such as SEWING ${ }^{[87]}$ (structure extension with native-substructure graphs) or AbDesign ${ }^{[88]}$ ) or by training machine learning models based on existing protein structures, including the most recent method of neural network $(\mathrm{NN})$ hallucination which uses the NN from transform-restrained (TR)-Rosetta. ${ }^{[89]}$

2. Optimizing the sequence composition and side chain rotamers to stabilize the backbone structure. Successful strategies include (a) layer design, which restricts amino acid possibilities at each residue position based on their solvent accessibility, ${ }^{\text {90] }}$ or (b) the HBNet[91] method, that involves identifying residues and side chain rotamers that support hydrogen bonded networks.

Designed proteins with tailor-made properties and functions have begun to make their mark in several areas; some noteworthy examples include the design of immunogens, ${ }^{[92]}$ targeted therapeutics, ${ }^{[93]}$ and biosensors. ${ }^{[94]}$ However, most of these protein design studies focus on water-soluble proteins, and no peripheral membrane proteins with specific lipid-binding properties have been designed so far to the best of our knowledge. We foresee that the design of proteins that specifically bind lipids such as PC, PE, or ceramides, for example, could help better understand the cellular localization and distribution pathways of these lipids.

\section{Conclusions and Outlook}

In this short review, we focused on lipid-binding proteins that can assist in visualizing lipid pools in cells, and some caveats of current methodologies such as the lack of probes for some common lipids. We propose that MD simulations and in silico design of lipid-binding proteins could help identify and validate membrane binding modes and lipid specificities of natural and artificially designed proteins. This will help elucidate lipid distribution and trafficking in cells when expressed in vitro or in vivo. We expect these methodologies to be paramount in filling crucial knowledge gaps in lipid biology.

\section{Acknowledgements}

This work was supported by the Swiss National Science Foundation (grant \#PP00P3_163966 and \#PP00P3_194807). This project has received funding from the European Research Council (ERC) under the European Union's Horizon 2020 research and innovation programme (Grant agreement No. 803952).

Received: October 4, 2021

[1] M. T. Nakamura, B. E. Yudell, J. J. Loor, Prog. Lipid Res. 2014, 53, 124, https://doi.org/10.1016/j.plipres.2013.12.001.

[2] H. Sunshine, M. L. Iruela-Arispe, Curr. Opin. Lipidol. 2017, 28, 408, https://doi.org/10.1097/MOL.0000000000000443.

[3] S. Vanni, L. Riccardi, G. Palermo, M. De Vivo, Acc. Chem. Res. 2019, 52, 3087, https://doi.org/10.1021/acs.accounts.9b00134.

[4] M. Sud, E. Fahy, D. Cotter, A. Brown, E. A. Dennis, C. K. Glass, A. H. Merrill, Jr., R. C. Murphy, C. R. Raetz, D. W. Russell, S. Subramaniam,
Nucl. Acids Res. 2007, 35, D527, https://doi.org/10.1093/nar/gk1838.

[5] G. van Meer, D. R. Voelker, G. W. Feigenson, Nat. Rev. Mol. Cell Biol. 2008, 9, 112, https://doi.org/10.1038/nrm2330.

[6] P. Várnai, G. Gulyás, D. J. Tóth, M. Sohn, N. Sengupta, T. Balla, Cell Calcium 2017, 64, 72, https://doi.org/10.1016/j.ceca.2016.12.008.

[7] D. Axelrod, D. E. Koppel, J. Schlessinger, E. Elson, W. W. Webb, Biophys. J. 1976, 16, 1055, https://doi.org/10.1016/S0006-3495(76)85755-4.

[8] Z. Li, E. Mintzer, R. Bittman, J. Org. Chem. 2006, 71, 1718 , https://doi.org/10.1021/jo052029x.

[9] K. Fukami, K. Matsuoka, O. Nakanishi, A. Yamakawa, S. Kawai, T. Takenawa, Proc. Natl. Acad. Sci. USA 1988, 85, 9057, https://doi.org/10.1073/pnas.85.23.9057.

[10] M. Atsuo, U. Masato, H. Tetsuro, Y. Keiji, Y. Tohoru, I. Keizo, Mol. Immunol. 1988, 25, 1025, https://doi.org/10.1016/0161-5890(88)90010-7.

[11] T. Kobayashi, E. Stang, K. S. Fang, P. de Moerloose, R. G. Parton, J. Gruenberg, Nature 1998, 392, 193, https://doi.org/10.1038/32440.

[12] M. Maekawa, G. D. Fairn, J. Cell Sci. 2014, 127, 4801, https://doi.org/10.1242/jcs.150524.

[13] R. C. Wills, B. D. Goulden, G. R. V. Hammond, Mol. Biol. Cell 2018, 29 , 1526, DOI: 10.1091/mbc.e17-12-0738.

[14] K. Moravcevic, J. M. Mendrola, K. R. Schmitz, Y.-H. Wang, D. Slochower, P. A. Janmey, M. A. Lemmon, Cell 2010, 143, 966, https://doi.org/10.1016/j.cell.2010.11.028.

[15] Y. Rao, V. Haucke, Cell Mol. Life Sci. 2011, 68, 3983, https://doi.org/10.1007/s00018-011-0768-5.

[16] S. Vanni, L. Vamparys, R. Gautier, G. Drin, C. Etchebest, P. F. J. Fuchs, B. Antonny, Biophys. J. 2013, 104, 575, https://doi.org/10.1016/j.bpj.2012.11.3837.

[17] M. Maekawa, Y. Yang, G. D. Fairn, Toxins 2016, 8, 67, https://doi.org/10.3390/toxins8030067.

[18] P. Buwaneka, A. Ralko, S. L. Liu, W. Cho, J. Lipid Res. 2021, 62, 100084 , https://doi.org/10.1016/j.jlr.2021.100084.

[19] R. V. Stahelin, M. A. Digman, M. Medkova, B. Ananthanarayanan, H. R. Melowic, J. D. Rafter, W. Cho, J. Biol. Chem. 2005, 280, 19784 https://doi.org/10.1074/jbc.M411285200.

[20] N. Kassas, E. Tanguy, T. Thahouly, L. Fouillen, D. Heintz, S. ChasserotGolaz, M. F. Bader, N. J. Grant, N. Vitale, J. Biol. Chem. 2017, 292, 4266, https://doi.org/10.1074/jbc.M116.742346.

[21] C. Zhao, G. Du, K. Skowronek, M. A. Frohman, D. Bar-Sagi, Nat. Cell. Biol. 2007, 9, 706, https://doi.org/10.1038/ncb1594.

[22] F. Zhang, Z. Wang, M. Lu, Y. Yonekubo, X. Liang, Y. Zhang, P. Wu, Y. Zhou, S. Grinstein, F. H. John, G. Du, Mol. Cell. Biol. 2014, 34, 84 https://doi.org/10.1128/MCB.00987-13.

[23] A. Gray, J. Van Der Kaay, C. P. Downes, Biochem. J. 1999, 344 Pt 3, 929-936.

[24] J. K. Klarlund, W. Tsiaras, J. J. Holik, A. Chawla, M. P. Czech, J. Biol. Chem. 2000, 275, 32816, https://doi.org/10.1074/jbc.M002435200.

[25] L. E. Rameh, A.-k. Arvidsson, K. L. Carraway, A. D. Couvillon, G. Rathbun, A. Crompton, B. VanRenterghem, M. P. Czech, K. S. Ravichandran, S. J. Burakoff, D.-S. Wang, C.-S. Chen, L. C. Cantley, J. Biol. Chem. 1997, 272, 22059, https://doi.org/10.1074/jbc.272.35.22059.

[26] K. Venkateswarlu, F. Gunn-Moore, P. B. Oatey, J. M. Tavaré, P. J. Cullen, Biochem. J. 1998, 335, 139, https://doi.org/10.1042/bj3350139.

[27] S. Dowler, R. A. Currie, D. G. Campbell, M. Deak, G. Kular, C. P. Downes, D. R. Alessi, Biochem. J. 2000, 351, 19, https://doi.org/10.1042/bj3510019.

[28] B. K. Han, S. D. Emr, Genes Dev. 2011, 25, 984 , https://doi.org/10.1101/gad.1998611

[29] S. Friant, E.-I. Pécheur, A. Eugster, F. Michel, Y. Lefkir, D. Nourrisson, F. Letourneur, Devel. Cell 2003, 5, 499, https://doi.org/10.1016/S1534-5807(03)00238-7.

[30] T. Itoh, S. Koshiba, T. Kigawa, A. Kikuchi, S. Yokoyama, T. Takenawa, Science 2001, 291, 1047, https://doi.org/10.1126/science.291.5506.1047.

[31] P. Garcia, R. Gupta, S. Shah, A. J. Morris, S. A. Rudge, S. Scarlata, V. Petrova, S. McLaughlin, M. J. Rebecchi, Biochem. 1995, 34, 16228 , https://doi.org/10.1021/bi00049a039.

[32] S. B. Lee, P. Várnai, A. Balla, K. Jalink, S. G. Rhee, T. Balla, J. Biol. Chem. 2004, 279, 24362, https://doi.org/10.1074/jbc.M312772200.

[33] K. V. Quinn, P. Behe, A. Tinker, J. Physiol. 2008, 586, 2855 , https://doi.org/10.1113/jphysiol.2008.153791.

[34] J.-M. Gaullier, A. Simonsen, A. D'Arrigo, B. Bremnes, H. Stenmark, R. Aasland, Nature 1998, 394, 432, https://doi.org/10.1038/28767.

[35] J. Bravo, D. Karathanassis, C. M. Pacold, M. E. Pacold, C. D Ellson, K. E. Anderson, P. J. Butler, I. Lavenir, O. Perisic, P. T Hawkins, L. Stephens, R. L. Williams, Mol. Cell 2001, 8, 829, https://doi.org/10.1016/S1097-2765(01)00372-0.

[36] A. Godi, A. Di Campli, A. Konstantakopoulos, G. Di Tullio, D. R. Alessi, G. S. Kular, T. Daniele, P. Marra, J. M. Lucocq, M. A. De Matteis, Nat. Cell Biol. 2004, 6, 393, https://doi.org/10.1038/ncb1119.

[37] Y. Liu, R. A. Kahn and J. H. Prestegard, Structure 2014, 22, 421, https://doi.org/10.1016/j.str.2013.12.011.

[38] T. P. Levine, S. Munro, Curr. Biol. 2002, 12, 695 , https://doi.org/10.1016/S0960-9822(02)00779-0. 
[39] A. Roy, T. P. Levine, J. Biol. Chem. 2004, 279, 44683, https://doi.org/10.1074/jbc.M401583200.

[40] G. R. V. Hammond, M. P. Machner, T. Balla, J. Cell Biol. 2014, 205, 113, https://doi.org/10.1083/jcb.201312072.

[41] S. Dolinsky, I. Haneburger, A. Cichy, M. Hannemann, A. Itzen, H. Hilbi, Infect. Immun. 2014, 82, 4021, https://doi.org/10.1128/IAI.01685-14.

[42] X. Luo, D. J. Wasilko, Y. Liu, J. Sun, X. Wu, Z.Q. Luo, Y. Mao, PLOS Pathogens 2015, 11, e1004965, https://doi.org/10.1371/journal.ppat.1004965.

[43] O. Gozani, P. Karuman, D. R. Jones, D. Ivanov, J. Cha, A. A. Lugovskoy, C. L. Baird, H. Zhu, S. J. Field, S. L. Lessnick, J. Villasenor, B. Mehrotra, J. Chen, V. R. Rao, J. S. Brugge, C. G. Ferguson, B. Payrastre, D. G. Myszka, L. C. Cantley, G. Wagner, N. Divecha, G. D. Prestwich, J. Yuan, Cell 2003, 114, 99, https://doi.org/10.1016/S0092-8674(03)00480-X.

[44] T. Yeung, E. Gilbert Gary, J. Shi, J. Silvius, A. Kapus, S. Grinstein, Science 2008, 319, 210, https://doi.org/10.1126/science.1152066

[45] A. Yamaji, Y. Sekizawa, K. Emoto, H. Sakuraba, K. Inoue, H. Kobayashi, M. Umeda, J. Biol. Chem. 1998, 273, 5300, https://doi.org/10.1074/jbc.273.9.5300.

[46] Y. Deng, F. E. Rivera-Molina, D. K. Toomre, C. G. Burd, Proc. Natl. Acad. Sci. USA 2016, 113, 6677, https://doi.org/10.1073/pnas.1602875113.

[47] S. Endapally, D. Frias, M. Grzemska, A. Gay, D. R. Tomchick, A. Radhakrishnan, Cell 2019, 176, P1040, https://doi.org/10.1016/j.cell.2018.12.042.

[48] W. Humphrey, A. Dalke, K. Schulten, J. Mol. Graphics 1996, 14, 33 , https://doi.org/10.1016/0263-7855(96)00018-5.

[49] A.-E. Saliba, I. Vonkova, S. Deghou, S. Ceschia, C. Tischer, K. G. Kugler, P. Bork, J. Ellenberg, A.-C. Gavin, Nat. Prot. 2016, 11, 1021, https://doi.org/10.1038/nprot.2016.059.

[50] T. W. Bumpus, J. M. Baskin, Trends Biochem. Sci. 2018, 43, 970, https://doi.org/10.1016/j.tibs.2018.09.011

[51] B. X. Huang, M. Akbar, K. Kevala, H. Y. Kim, J. Cell Biol. 2011, 192, 979 , https://doi.org/10.1083/jcb.201005100.

[52] C. C. Milburn, M. Deak, S. M. Kelly, N. C. Price, D. R. Alessi, D. M. Van Aalten, Biochem. J. 2003, 375, 531, https://doi.org/10.1042/bj20031229.

[53] J. E. Johnson, R. B. Cornell, Mol. Membr. Biol. 1999, 16, 217, https://doi.org/10.1080/096876899294544.

[54] S.-B. T. A. Amos, A. C. Kalli, J. Shi, M. S. P. Sansom, Structure 2019, 27, 1336, https://doi.org/10.1016/j.str.2019.05.004.

[55] A. Buyan, A. C. Kalli, M. S. Sansom, PLoS Comput. Biol. 2016, 12 , e1005028, https://doi.org/10.1371/journal.pcbi.1005028.

[56] S. Vanni, H. Hirose, H. Barelli, B. Antonny, R. Gautier, Nat. Commun. 2014, 5, 4916, https://doi.org/10.1038/ncomms5916.

[57] J. M. von Filseck, S. Vanni, B. Mesmin, B. Antonny, G. Drin, Nat. Commun. 2015, 6, 6671, https://doi.org/10.1038/ncomms7671

[58] E. Yamamoto, A. C. Kalli, K. Yasuoka, M. S. P. Sansom, Structure 2016, 24, 1421, https://doi.org/10.1016/j.str.2016.06.002.

[59] A. Grabon, A. Orłowski, A. Tripathi, J. Vuorio, M. Javanainen, T. Róg, M. Lönnfors, M. I. McDermott, G. Siebert, P. Somerharju, I. Vattulainen, V. A. Bankaitis, J. Biol. Chem. 2017, 292, 14438, https://doi.org/10.1074/jbc.M117.791467.

[60] P. D. Revanasiddappa, R. Sankar, S. Senapati, J. Phys. Chem. B 2018, 122, 4239, https://doi.org/10.1021/acs.jpcb.7b12095.

[61] R. P. Singh, B. R. Brooks, J. B. Klauda, Proteins 2009, 75, 468 https://doi.org/10.1002/prot.22263.

[62] B. Rogaski, J. B. Klauda, J. Mol. Biol. 2012, 423, 847, https://doi.org/10.1016/j.jmb.2012.08.015.

[63] H. M. Khan, T. He, E. Fuglebakk, C. Grauffel, B. Yang, M. F. Roberts, A. Gershenson, N. Reuter, Biophys. J. 2016, 110, 1367, https://doi.org/10.1016/j.bpj.2016.02.020.

[64] M. Moqadam, T. Tubiana, E. E. Moutoussamy, N. Reuter, Adv. Phys. X 2021, 6, 1932589, https://doi.org/10.1080/23746149.2021.1932589.

[65] Y. Z. Ohkubo, T. V. Pogorelov, M. J. Arcario, G. A. Christensen, E. Tajkhorshid, Biophys. J. 2012, 102, 2130, https://doi.org/10.1016/j.bpj.2012.03.015.

[66] S. Pant, E. Tajkhorshid, J. Comput. Chem. 2020, 41, 489, https://doi.org/10.1002/jcc.26109.

[67] T. V. Pogorelov, J. V. Vermaas, M. J. Arcario, E. Tajkhorshid, J. Phys. Chem. B 2014, 118, 1481, https://doi.org/10.1021/jp4089113.

[68] M. Cascella, S. Vanni, in 'Chemical Modelling: Volume 12', The Royal Society of Chemistry, 2016, vol. 12, pp. 1-52.

[69] S. J. Marrink, H. J. Risselada, S. Yefimov, D. P. Tieleman, A. H. de Vries, J. Phys. Chem. B 2007, 111, 7812, https://doi.org/10.1021/jp071097f.

[70] P. C. T. Souza, R. Alessandri, J. Barnoud, S. Thallmair, I. Faustino, F. Grünewald, I. Patmanidis, H. Abdizadeh, B. M. H. Bruininks, T. A Wassenaar, P. C. Kroon, J. Melcr, V. Nieto, V. Corradi, H. M. Khan, J. Domański, M. Javanainen, H. Martinez-Seara, N. Reuter, R. B. Best, I. Vattulainen, L. Monticelli, X. Periole, D. P. Tieleman, A. H. de Vries, S. J. Marrink, Nat. Meth. 2021, 18, 382, DOI: 10.1038/s41592-021-01098-3.

[71] S. Srinivasan, V. Zoni, S. Vanni, Faraday Discuss. 2021, https://doi.org/10.1039/D0FD00058B.
72] F. B. Naughton, A. C. Kalli, M. S. P. Sansom, J. Mol. Biol. 2018, 430, 372, https://doi.org/10.1016/j.jmb.2017.12.011.

[73] C. N. Lumb, M. S. P. Sansom, Biophys. J. 2013, 104, 613.

[74] H. M. Khan, P. C. T. Souza, S. Thallmair, J. Barnoud, A. H. de Vries S. J. Marrink, N. Reuter, J. Chem. Theor. Comput. 2020, 16, 2550, https://doi.org/10.1021/acs.jctc.9b01194.

[75] A. Koivuniemi, T. Vuorela, P. T. Kovanen, I. Vattulainen, M. T. Hyvönen, PLOS Comput. Biol. 2012, 8, e1002299, https://doi.org/10.1371/journal. pcbi.1002299.

[76] C. Lamprakis, A. Stocker, M. Cascella, Front. Mol. Biosci. 2015, 2 , https://doi.org/10.3389/fmolb.2015.00036.

[77] J. Jumper, R. Evans, A. Pritzel, T. Green, M. Figurnov, O. Ronneberger, K. Tunyasuvunakool, R. Bates, A. Žídek, A. Potapenko, A. Bridgland, C. Meyer, S. A. A. Kohl, A. J. Ballard, A. Cowie, B. Romera-Paredes, S Nikolov, R. Jain, J. Adler, T. Back, S. Petersen, D. Reiman, E. Clancy, M Zielinski, M. Steinegger, M. Pacholska, T. Berghammer, S. Bodenstein, D. Silver, O. Vinyals, A. W. Senior, K. Kavukcuoglu, P. Kohli, D. Hassabis, Nature 2021, 596, 583, https://doi.org/10.1038/s41586-021-03819-2.

[78] M. A. Lemmon, K. M. Ferguson, Biochem. J. 2000, 350 Pt 1, 1-18.

[79] N. Bhardwaj, R. V. Stahelin, R. E. Langlois, W. Cho, H. Lu, J. Mol. Biol. 2006, 359, 486, https://doi.org/10.1016/j.jmb.2006.03.039.

[80] A. Chatzigoulas, Z. Cournia, bioRxiv 2021 , https://doi.org/10.1101/2021.06.28.450157, 2021.2006.2028.450157.

[81] E. Fuglebakk, N. Reuter, PLOS Comput. Biol. 2018, 14, e1006325, https://doi.org/10.1371/journal.pcbi.1006325.

[82] W. A. Lim, R. T. Sauer, Nature 1989, 339, 31 https://doi.org/10.1038/339031a0.

[83] S. Nauli, B. Kuhlman, D. Baker, Nat. Struct. Biol. 2001, 8, 602 https://doi.org/10.1038/89638.

[84] P. B. Harbury, J. J. Plecs, B. Tidor, T. Alber, S. K. Peter, Science 1998, 282 , 1462, https://doi.org/10.1126/science.282.5393.1462.

[85] X. Pan, T. Kortemme, J. Biol. Chem. 2021, 296, 100558, https://doi.org/10.1016/j.jbc.2021.100558.

[86] H. M. Berman, J. Westbrook, Z. Feng, G. Gilliland, T. N. Bhat, H Weissig, I. N. Shindyalov, P. E. Bourne, Nucl. Acids Res. 2000, 28, 235 , https://doi.org/10.1093/nar/28.1.235.

[87] T. M. Jacobs, B. Williams, T. Williams, X. Xu, A. Eletsky, J. F. Federizon, T. Szyperski, B. Kuhlman, Science 2016, 352, 687, https://doi.org/10.1126/science.aad8036.

[88] R. Lipsh-Sokolik, D. Listov, S. J. Fleishman, Protein Sci. 2021, 30, 151, https://doi.org/10.1002/pro.3970.

[89] J. Yang, I. Anishchenko, H. Park, Z. Peng, S. Ovchinnikov, D. Baker, Proc. Natl. Acad. Sci. USA 2020, 117, 1496, https://doi.org/10.1073/pnas.1914677117.

[90] N. Koga, R. Tatsumi-Koga, G. Liu, R. Xiao, T. B. Acton, G. T. Montelione, D. Baker, Nature 2012, 491, 222, https://doi.org/10.1038/nature11600.

[91] S. E. Boyken, Z. Chen, B. Groves, R. A. Langan, G. Oberdorfer, A. Ford, J. M. Gilmore, C. Xu, F. DiMaio, J. H. Pereira, B. Sankaran, G. Seelig, P. H. Zwart, D. Baker, Science 2016, 352, 680 , https://doi.org/10.1126/science.aad8865.

[92] F. Sesterhenn, C. Yang, J. Bonet, T. Cramer Johannes, X. Wen, Y. Wang, I. Chiang Chi, A. Abriata Luciano, I. Kucharska, G. Castoro, S. Vollers Sabrina, M. Galloux, E. Dheilly, S. Rosset, P. Corthésy, S. Georgeon, M. Villard, C.A. Richard, D. Descamps, T. Delgado, E. Oricchio, M.-A. Rameix-Welti, V. Más, S. Ervin, J.-F. Eléouët, S. Riffault, T. Bates John, J.-P. Julien, Y. Li, T. Jardetzky, T. Krey, E. Correia Bruno, Science 2020, 368, eaay5051, https://doi.org/10.1126/science.aay5051.

[93] A. Chevalier, D.-A. Silva, G. J. Rocklin, D. R. Hicks, R. Vergara, P. Murapa, S. M. Bernard, L. Zhang, K.-H. Lam, G. Yao, C. D. Bahl, S.-I. Miyashita, I. Goreshnik, J. T. Fuller, M. T. Koday, C. M. Jenkins, T. Colvin, L. Carter, A. Bohn, C. M. Bryan, D. A. Fernández-Velasco, L. Stewart, M. Dong, X Huang, R. Jin, I. A. Wilson, D. H. Fuller, D. Baker, Nature 2017, 550, 74, https://doi.org/10.1038/nature23912.

[94] A. Quijano-Rubio, H.-W. Yeh, J. Park, H. Lee, R. A. Langan, S. E. Boyken, M. J. Lajoie, L. Cao, C. M. Chow, M. C. Miranda, J. Wi, H. J. Hong, L. Stewart, B.-H. Oh, D. Baker, Nature 2021, 591, 482, https://doi.org/10.1038/s41586-021-03258-z.

\section{License and Terms}

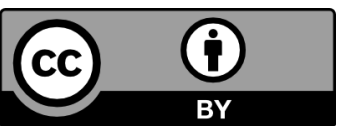

This is an Open Access article under the terms of the Creative Commons Attribution License CC BY 4.0. The material may not be used for commercial purposes.

The license is subject to the CHIMIA terms and conditions: (http:// chimia.ch/component/sppagebuilder/?view=page \&id=12).

The definitive version of this article is the electronic one that can be found at https://doi.org/10.2533/chimia.2021.1031 